\title{
PRINSIP COMMON BUT DIFFERENTIATED RESPONSIBILITY DALAM PENGELOLAAN LINGKUNGAN HIDUP, SUMBER DAYA ALAM DAN HUTAN TROPIS
}

\author{
Sri Rahayu Oktoberina ${ }^{1}$ dan Tristam M. Moeliono \\ email: tristam_m@yahoo.com
}

\begin{abstract}
The common but differentiated responsibility is or will become an important principle of international environmental law, specifically related to the management of tropical rain forest. The issue at hand is how this principle is understood by developing states, which by its geographical position, is entrusted with the responbility to manage tropical rain forest. In this article the author traces the reason justifying the differentiation of (international) responsibilities and attempts to relate this (mis-) understanding of the principle to Indonesia's unwillingness or inability to manage its tropical rain forest.
\end{abstract}

Keywords:

common but differentiated responsibility; tropical forest management

\begin{abstract}
Abstrak
Gagasan Common but Differentiated Responsibility ditengarai sudah atau akan menjadi prinsip penting dalam hukum lingkungan internasional, khususnya berkaitan dengan pengelolaan hutan hujan tropika. Persoalannya adalah bagaimana prinsip CBDR ini dimaknai terutama oleh Negaranegara yang karena posisi geografis menguasai hutan hujan tropika. Tulisan ini menelusuri rationale dibalik pembedaan tanggungjawab (hukum) internasional antara negara maju dengan Negara berkembang dan mencoba mengaitkannya pada ketidak (mau-an atau sanggupan) Negara Indonesia mengelola dengan baik hutan hujan tropika yang berada di bawah kedaulatan teritorialnya.
\end{abstract}

Kata kunci: common but differentiated responsibility, pengelolaan hutan tropis.

\section{Pengantar}

Kawasan hutan hujan tropika (tropical rain forest) hanya dapat ditemukan di negara-negara yang berada di bentangan khatulistiwa, terutama Indonesia dan Brazil. Hutan hujan tropika ditengarai merupakan paru-paru bumi dan situs bagi kekayaan alam (flora-fauna) yang sudah atau belum tereksploitasi berupa

1 Tulisan ini merupakan rangkuman dari bagian disertasi yang disampaikan dalam Seminar Kemajuan Penelitian pada Mei 2016 dan ditulis ulang oleh Tristam P. Moeliono sebagai kenangan akan alm. Ibu Sri Rahayu Oktoberina, dosen Fakultas Hukum UNPAR dan mahasiswa Program Doktoral UNPAR. Beliau meninggal sebelum sempat menuntaskan program doktoralnya di bawah bimbingan Huala Adolf (UNPAD) dan Tristam P. Moeliono (UNPAR). 
keanekaragaman hayati (bio-diversity). ${ }^{2}$ Pengelolaan secara berkelanjutan dan penghindaran perusakan terhadap hutan menjadi perhatian masyarakat internasional. Tidak mengherankan hutan hujan tropika dinyatakan sebagai warisan bersama umat manusia (common heritage of mankind) yang sebab itu harus dikelola bersama oleh Negara-negara yang ada di muka bumi (masyarakat internasional) secara berkelanjutan. ${ }^{3}$ Disebutkan ten Have bahwa hutan hujan tropis dikategorikan sebagai common heritage karena dipandang: ${ }^{4}$

(..) vital for the survival of humankind. It also means defining global responsibilities. Common areas cannot be appropriated. They demand international cooperation in order to create common management. Possible benefit should be equally shared among states, irrespective of their geography. They should be used for peaceful purposes. And finally, it is necessary to preserve them for future generations.

Apakah betul kawasan hutan yang terutama berada di dalam wilayah Negara-negara berkembang dapat sepenuhnya diletakan di luar lingkup yurisdiksi hukum Negara tersebut merupakan persoalan lain. Namun untuk sementara cukup dikatakan bahwa pengkategorian hutan hujan tropis menunjukkan kepedulian atau perhatian masyarakat internasional terhadap keberlanjutan lingkungan hidup secara umum dan hutan khususnya dalam menunjang kehidupan manusia (carrying capacity).

2 At the 1992 Earth Summit in Rio de Janeiro, world leaders agreed on a comprehensive strategy for "sustainable development" - meeting our needs while ensuring that we leave a healthy and viable world for future generations. One of the key agreements adopted at Rio was the Convention on Biological Diversity. (...) The Convention has three main goals: • The conservation of biodiversity, • Sustainable use of the components of biodiversity, and - Sharing the benefits arising from the commercial and other utilization of genetic resources in a fair and equitable way. Periksa: https://www.cbd.int/ Bandingkan pula dengan: Secretariat of the Convention on Biological Diversity (2000), Sustaining life on Earth: How the Convention on Biological Diversity promotes nature and human well-being, the United Nations Environment Programme (UNEP). Indonesia telah menandatangani (1992-06-05) dan meratifikasi (1994-08-23) Konvensi ini.

${ }^{3}$ Henk ten Have (2016), Global Bioethics: An Introduction, New York. Routledge. Ia menyebutkan bahwa kategori common heritage yang dahulu dilekatkan pada sumberdaya atau benda-benda di luar wilayah Negara (Antartica, Ocean floor and deep sea-bed, the moon and other celestial bodies) sekarang ini juga diberikan pada hutan hujan tropis, hlm. 117.

4 Id. 
Adanya perkaitan antara keberlanjutan hidup umat manusia dengan kelestarian lingkungan hidup merupakan titik tolak diselenggarakannya konferensi di Stockholm pada 19725, dan kemudian di Rio de Janeiro pada 1992. Pertemuan pada 1992 ini menghasilkan pertama, Rio Declaration yang memuat prinsip-prinsip umum pengelolaan lingkungan hidup dan kedua, adalah the forest principles (non-legally binding authoritative statement of principles for a global consensus on the management, conservation and sustainable development of all types of forests) yang secara khusus memuat prinsip atau arahan pengelolaan hutan (termasuk hutan tropis) ${ }^{6}$ dan juga Konvensi tentang Keanekaragaman Hayati yang sudah disebut di atas.

Di balik perdebatan tentang apakah norma-norma yang termuat di dalam dokumen-dokumen di atas memiliki atau tidak memiliki kekuatan mengikat sebagai hukum (soft law-hard law atau sebagai non-binding namun authoritative statements), kesemua itu, bagaimanapun juga, dapat dipandang dan dimaknai sebagai kompromi politik antara Negara-negara berkembang (terutama yang menguasai hutan hujan dan memiliki kebutuhan untuk mengeksploitasi sumber daya alam) dengan Negara-negara maju yang memiliki sudut pandang berbeda tentang bagaimana sebaiknya dan seharusnya hutan hujan dikelola bersamasama.

Pada lain pihak kita dapat mencermati bagaimana sebenarnya Negara berkembang (Indonesia) yang di dalam wilayahnya (kedaulatan teritorial) ditemukan bentangan hutan hujan tropika yang mengandung keanekaragaman

5 The United Nations Conference on the Human Environment (Stockholm; 5-16 Juni 1972) menghasilkan Declaration of the United Nations Conference on the Human Environment. Naskah lengkap dapat dilihat di http://www.unep.org/documents.multilingual/default.asp? documentid=97\&articleid $=1503$.

6 A/CONF.151/26 (Vol. III); General Assembly Distr. GENERAL 14 August 1992. REPORT OF THE UNITED NATIONS CONFERENCE ON ENVIRONMENT AND DEVELOPMENT (Rio de Janeiro, 3-14 June 1992) Annex III:NON-LEGALLY BINDING AUTHORITATIVE STATEMENT OF PRINCIPLESFOR A GLOBAL CONSENSUS ON THE MANAGEMENT, CONSERVATION AND SUSTAINABLE DEVELOPMENT OF ALL TYPES OF FORESTS 
hayati besar. Indonesia justru menunjukkan semangat eksploitasi kawasan hutan yang jelas tidak berkelanjutan. Laporan yang dihimpun FAO menunjukkan bahwa dalam kurun waktu 10 tahun (2000-2010) dunia terus kehilangan kawasan hutan tropis tiap tahunnya seluas Costa Rica. ${ }^{7}$ Dirincikan bahwa Brazil kehilangan 2,6 juta hektar/tahun, sedangkan Indonesia 1,9 juta hektar/tahun. Data lain menunjukkan bahwa Indonesia mengalami deforestasi (2000-2012) sebesar 6.02 juta hektar/tahun. Meningkat sekitar 47, 600 hektar per tahun melampaui Brazil. Padahal luas tutupan Indonesia hanya $1 / 4$ luas hutan di Brazil. ${ }^{8}$ Bahkan penilaian UNDP, khusus untuk Indonesia pada 2012 dalam tata kelola hutan, lahan dan REDD+ adalah 2,33 dalam skala dengan nilai tertinggi 5. Belum lagi kita dapat rujuk ketidak (mampuan atau mau-an) Indonesia selama berdekade untuk mencegah dan menanggulangi kebakaran hutan hampir di seluruh wilayah Indonesia (terutama Sumatera \& Kalimantan) yang muncul setiap tahunnya. ${ }^{9}$

Angka-angka di atas jelas dan kecenderungan yang muncul darinya jelas menunjukkan ada yang salah dalam pola pengelolaan hutan di Indonesia. Mengapa Indonesia tidak (mau atau mampu) peduli pada urusan pemeliharaan

7 FAO, World Deforestation Decrease, but Remains Alarming in Many Countries. http://www.fao.org/news/story/en/item/40893/icode/

8 John Vidal, "Rate of deforestation in Indonesia overtakes Brazil, says study", https://www.theguardian.com/environment/2014/jun/29/. Menurut peneliti Belinda Arunawati Margono, data diperoleh dari remote sensing.

9 Dicermati bahwa: Forest fires have become a seasonal phenomenon in Indonesia. (...). Sedangkan berkaitan dengan pencarian dan penetapan siapa yang seharusnya dapat dimintakan tanggungjawab diamati bahwa: It's a blame game, with everyone pointing the finger at someone else. Environmental group WWF Indonesia, which has been highlighting the problem of Indonesia's recurrent fires for years, says that the fires are caused by the "collective negligence" of companies, smallholders and government (which isn't investing sufficiently in preventative measures). Many blame big business. Baca: Indonesia's forest fires: everything you need to know: The fires devastating Indonesia have been called a 'crime against humanity'. How did they start, what damage are they causing and who's to blame? https://www.theguardian.com/sustainablebusiness/2015/nov/11/indonesia-forest-fires-explained-haze-palm-oil-timber-burning.

Bandongkan pula: Sarah Porte, "Can Indonesia's forest fires be put out for good?" http://www.bbc.com/news/business-35770490. Ia mengutip pandangan Dian Patria, acting director of research and development at Indonesia's Corruption Eradication Commission, yang menyatakan: the biggest challenge is that no-one wants to be held responsible for the decades-old problem. "There has been bad governance and bad management of the forests, based on our study of the last 12 years, and everyone says it is the fault of the previous minister, or previous governor," 
kelestarian hutan hujan tropika, padahal kelestarian hutan terkait langsung dengan keberlangsungan umat manusia? Bagaimanakah Indonesia sebenarnya memaknai kewajiban hukum internasionalnya? Pertanyaan ini sekaligus memunculkan persoalan lain tentang bagaimana hukum lingkungan internasional memandang pembagian tanggung jawab antara Negara maju dengan Negara berkembang seperti Indonesia, khususnya berkaitan dengan pengelolaan sumberdaya alam atau lingkungan yang jelas menyangkut nasib dan hajat hidup umat manusia.

Pertanyaan-pertanyaan di atas tersebut akan menjadi fokus tulisan ini. Jawaban terhadap persoalan-persoalan ini akan dikaji dengan menggunakan sudut pandang hukum (lingkungan) internasional dan sebab itu fokus telaahan ini akan terpusat pada dokumen-dokumen hukum lingkungan internasional yang terkait. Beranjak dari itu titik tolaknya adalah pengertian dan pemahaman yang berkembang tentang konsep pembangunan berkelanjutan sebagai norma hukum dan etis yang di dalamnya memuat sejumlah besar konsep-konsep lain. Argumen utama tulisan ini adalah pengaitan konsep pembangunan berkelanjutan pada keadilan (environmental-ecological justice) serta inter/intra generational equity yang besar pengaruhnya pada pemahaman dari common management, terutama dari hutan hujan tropika yang dikategorikan sebagai common heritage of mankind. Pada saat sama hambatan utama yang muncul adalah bahwa prinsip di atas dibangun (dan berbenturan) dengan prinsip utama dalam hukum internasional umum: penghormatan atas kedaulatan absolut dari Negara-negara ${ }^{10}$ termasuk the right to development dari terutama Negara-negara berkembang. ${ }^{11}$ Dalam hal ini,

${ }^{10}$ Art. 2 (1) UN Charter: The Organization is based on the principle of the sovereign equality of all its Members.

11 The right to development was proclaimed in the Declaration on the Right to Development, adopted in 1986 by the United Nations General Assembly (GA) in its resolution 41/128. This right is also recognized in the African Charter on Human and Peoples' Rights and the Arab Charter on Human Rights and re-affirmed in several instruments including the 1992 Rio Declaration on Environment and Development, the 1993 Vienna Declaration and Programme of Action, the 
mis-management kawasan hutan dan lingkungan oleh Indonesia untuk sebagian besar juga dipengaruhi kelemahan-kelemahan yang ada dalam pengaturan dan pembagian tanggung jawab dalam hukum lingkungan internasional.

\section{Makna dan Cakupan Pengertian Sustainable Development}

Deklarasi Stockholm dan Rio serupa dengan Forest principles (yang merupakan pengejawantahan prinsip-prinsip umum dari Deklarasi Stockholm dan Rio ke dalam pengelolaan hutan) memuat komitmen-komitmen yang mengikat Negara-negara sekalipun bukan atau tidak niscaya dalam artian hukum (nonbinding authoritative statements). Dengan kata lain, prinsip-prinsip yang termuat di dalamnya dapat dipandang sebagai soft $\operatorname{law}^{12}$ (yang dikontraskan dengan hard

\footnotetext{
Millennium Declaration, the 2002 Monterrey Consensus, the 2005 World Summit Outcome Document and the 2007 Declaration on the Rights of Indigenous Peoples. Under the Declaration, "States have the primary responsibility for the creation of national and international conditions favourable to the realization of the right to development" (Article 3). According to the high-level task force on the implementation of the right to development "the responsibility for the creation of this enabling environment encompasses three main levels: (a) States acting collectively in global and regional partnerships (second preambular paragraph and Article 3); (b) States acting individually as they adopt and implement policies that affect persons not strictly within their jurisdiction (Article 4); and (c) States acting individually as they formulate national development policies and programmes affecting persons within their jurisdiction (Article 2)." Baca lebih lanjut: http://www.un.org/en/events/righttodevelopment/pdf/ rtd_at_a_glance.pdf

12 Untuk diskusi tentang kekuatan mengikat dari principles sebagai soft law atau lainnnya (wujud dari customary international law atau general principles of law) dalam hukum lingkungan internasional baca lebih lanjut: Winfried Lang, UN-Principles and International Environmental Law, Max Planck UNYB 3 (1999):157-172. Penulis di dalam kesimpulan merekomendasikan dibuatnya 3 kategori prinsip yang dikaitkan dengan daya atau kekuatan mengikatnya (legallybinding/compulsory nature): existing; emerging dan potential principles of International Environmental Law. Ke dalam kelompok pertama adalah principle of responsibility/liability for environmental damage (domestic atau transboundary). Sedangkan yang termasuk ke dalam yang emerging principles adalah intergenerational equity as duty due to future generations, right to a healthy environment, procedural duties, notification and information in case of imminent danger or of potential damage possibly caused by certain activities. Kategori ketiga (potential principles): area of hope for many policy-makers mencakup: development and integration of environmental considerations into the development process, common but differentiated responsibilities (the low standing of this principle is due to its collision with the rule of sovereign equality) dan precautionary (principle). (171).
} 
law) ${ }^{13}$ yang memuat kesepakatan untuk mengikatkan diri dan menerima konsekuensi hukum darinya dengan lebih tegas. Kendati begitu komitmen untuk melaksanakan pembangunan berkelanjutan tidak dapat dan boleh dikesampingkan begitu saja. Setidaknya di atas kertas setiap Negara (anggota PBB) akan bersepakat untuk menjalankan prinsip-prinsip yang termuat dalam gagasan pembangunan berkelanjutan. Ini dikatakan dengan memperhatikan pula kenyataan bahwa Indonesia sudah menandatangani dan meratifikasi Konvensikonvensi lain, seperti Convention on Biological Diversity, yang memuat dan menegaskan prinsip-prinsip yang diusung dokumen-dokumen yang non-binding but authoritative di atas

Sebagai suatu gagasan payung konsep sustainable development ternyata tidak akan kita temukan definisinya di dalam Stockholm declaration (1972). Sedangkan di dalam Rio Declaration (1992) dan Forest Principles (1992), konsep ini disebut-sebut, namun juga tanpa didefinisikan lebih lanjut. Sekalipun konsep itu jelas dimaksud sebagai titik tolak untuk memahami dan membatasi hak berdaulat Negara untuk mengeksploitasi sumber daya alam (lingkungan) sesuai kebijakan lingkungan Negara dan kebutuhan pembangunan. Prinsip 2 (a) Forest principles menegaskan:

States have the sovereign and inalienable right to utilize, manage and develop their forests in accordance with their development needs and level of socio-economic development and on the basis of national policies consistent with sustainable development and legislation,

\footnotetext{
13 Dalam pelbagai literatur selalu disebut sebagai sumber hukum internasional (public) adalah: $a$. international conventions, whether general or particular, establishing rules expressly recognized by the contesting states; $b$. international custom, as evidence of a general practice accepted as law; $c$. the general principles of law recognized by civilized nations; $d$. subject to the provisions of Article 59, judicial decisions and the teachings of the most highly qualified publicists of the various nations, as subsidiary means for the determination of rules of law. (Art. 38 of the Statute of the International Court of Justice). Baca pula: Fitzmaurice, Malgosia, History of Article 38 of the Statute of the International Court of Justice (May 3, 2016). Queen Mary School of Law Legal Studies Research Paper No. 232/2016. Available at https://ssrn.com/sol3/astract=2774354. Ia menyebutkan bahwa sudah sejak perancangan Pasal 38 ini peran sumber hukum internasional lainnya, seperti acts of international organisations, unilateral acts of States, soft law sudah muncul.
} 
including the conversion of such areas for other uses within the overall socio-economic development plan and based on rational land-use policies.

Definisi umum yang sering dikutip menyebutkan bahwa pembangunan berkelanjutan adalah: ${ }^{14}$

Development that meets the needs of the present without compromising the ability of future generations to meet their own needs.

Tersembunyi atau terkait di dalam rumusan ini kewajiban untuk merancang pembangunan berdasarkan rasa keadilan (environmental-ecological justice) dan inter-intra generational equity. Hal ini kiranya sejalan dengan pandangan Sands yang menyatakan konsep sustainable development merangkum 4 elemen yang juga muncul tersendiri dalam berbagai kesepakatan internasional, yaitu the need to preserve natural resources for the benefit of future generations (the principle of intergenerational equity); the aim of exploiting natural resources in a manner which is sustainable or prudent or rational or wise or appropriate (the principle of sustainable use); the equitable use of natural resources, which implies that use by one state must take account the needs of other states (the principle of equitable use, or intragenerational equity) dan the need to ensure that environmental considerations are integrated into economic and other developmental plans, programmes and projects and that development needs are taken into account in applying environmental objectives (the principle of integration). 15

Selain itu, perumusan konsep pembangunan berkelanjutan seperti di atas meniscayakan Negara untuk mengembangkan kebijakan-kebijakan pembangunan yang memperhatikan dan menyeimbangkan upaya pencapaian tiga elemen sekaligus: sosial, ekonomi dan lingkungan. Itu sebabnya IUCN mendefinisikan

\footnotetext{
${ }^{14}$ The World Commission on Environment and Development's (the Brundtland Commission), Report (1987): Our Common Future, Oxford: Oxford University Press.

15 Phillippe Sands et al. (eds), (2012), Principles of International Environmental Law, $3^{\text {rd }}$ ed. Cambridge University Press. hlm. 207.
} 
pembangunan berkelanjutan sebagai strategi untuk ${ }^{16}$ : improving the quality of life while living within the carrying capacity of supporting ecosystems. Beranjak dari itu, maka konsep pembangunan berkelanjutan dapat digambarkan sebagai berikut: ${ }^{17}$

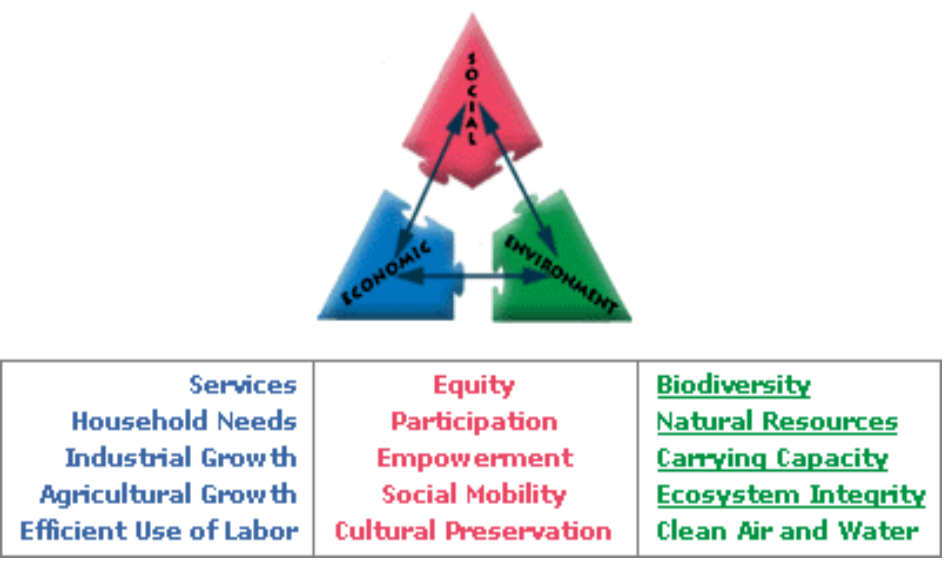

Ketiga elemen (dengan tujuan-tujuan khusus di dalamnya) tersebut harus dipaduserasikan dan menjadi landasan pengembangan kebijakan (policy) Negara untuk mengelola-memanfaatkan sumber daya alam (lingkungan) untuk pembangunan. Karena ${ }^{18}$ :

the overall goal of sustainable development (SD) is the long-term stability of the economy and environment; this is only achievable through the integration and acknowledgement of economic, environmental, and social concerns throughout the decision making process.

\footnotetext{
${ }_{16}$ IUCN/UNEP/WWF. (1991), Caring for the Earth: A Strategy for Sustainable Living, Gland, Switzerland.

$17 \mathrm{http} / / /$ www.worldbank.org/depweb/english/sd.html; lema What is sustainable development. $(10 / 18 / 2016)$.

18 Rachel Emas, Brief for GSDR 2015, "The Concept of Sustainable Development: Definition and Defining Principles" https://sustainabledevelopment.un.org/content/documents/5839GSDR\% 202015_SD_concept_definiton_rev.pdf Gambar atau skema di atas juga diperoleh dari tulisan ini.
} 
Dari kutipan-kutipan di atas kiranya jelas bahwa pertama-tama ${ }^{19}$

Sustainability and sustainable development are effectively ethical concepts, expressing desirable outcomes from economic and social decisions. The term 'sustainable' is therefore applied loosely to policies to express this aspiration, or to imply that the policy choice is 'greener than it might otherwise be (e.g. the idea of a 'sustainable road building programme').

Artinya Negara-negara ketika merujuk pada konsep ini, tidak melakukannya (implementasi dan penegakan dalam hukum nasional) karena hal itu terutama merupakan kewajiban di bawah hukum internasional. Sebaliknya dapat dikatakan Negara-negara cenderung memandang prinsip pembangunan berkelanjutan sebagai anjuran moral atau etis. Selanjutnya, komitmen (politik atau moraletikal) Negara - yang pada akhirnya harus diakui bersifat tidak mengikat sebagai hukum - untuk melaksanakan pembangunan berkelanjutan bertitik tolak dari pertama pengakuan (hukum) adanya hak berdaulat Negara atas sumber daya alam (lingkungan termasuk hutan) di dalam wilayahnya. Sekalipun pada saat sama kebebasan itu dibatasi oleh "responsibility to ensure that activities within their jurisdiction or control do not cause damage to the environment of other States or of areas beyond the limits of national jurisdiction" yang merupakan prinsip hukum umum yang ditegaskan kembali baik oleh ketiga instrumen hukum lingkungan internasional di atas. ${ }^{20}$

19 W.M. Adams, The Future of Sustainability: Re-thinking Environment and Development in the Twenty-first Century; Report of the IUCN Renowned Thinkers Meeting, 29-31 January 2006; www.iucn.org. pp. 3-5.

${ }^{20}$ A cornerstone rule of international environmental law is that states are under an obligation not to cause harm to the environment of other states, or to the areas beyond national jurisdiction. The essence of this obligation, often referred to as the no-harm rule or the prohibition of transboundary environmental harm, is that states may not conduct or permit activities within their territories, or in common spaces, without regard to other states or for the protection of the global environment. The origins of the obligation lie in the old principle of international law that states are obliged not to inflict damage on, or violate the rights of other states, which is often expressed by reference to the sic utere tuo ut alienum non laedas principle (use your own property in such a way that you do not injure other people's). Baca lebih lanjut: Jervan, Marte, The Prohibition of Transboundary Environmental Harm. An Analysis of the Contribution of the International Court of Justice to the 
Kombinasi dari komitmen moral atau etis dan kewajiban hukum ini dituntut pada baik Negara maju maupun Negara berkembang dan pada tataran nasional diwujudkan dalam peraturan perundang-undangan, regulasi dan/atau kebijakan-kebijakan di bidang pembangunan, ekonomi, perlindungan-pelestarian lingkungan atau lebih spesifik: pengelolaan kawasan hutan.

Namun gambaran ideal di atas tentang peluang menyelaraskan atau melakukan trade off antara tiga kepentingan berbeda-beda justru dipandang sebagai titik lemah pengertian pembangunan berkelanjutan dan pengejawantahannya ke dalam kebijakan-kebijakan pembangunan berdasarkan prinsip-prinsip keberlanjutan di atas. Dinyatakan: ${ }^{21}$

The three 'pillars' cannot be treated as if equivalent. First, the economy is an institution that emerges from society: these are in many ways the same, the one a mechanism or set of rules created by society to mediate the exchange of economic goods or value. The environment is different, since it is not created by society. Thinking about trade-offs rarely acknowledges this. Second, the environment underpins both society and economy. The resources available on earth and the solar system effectively present a finite limit on human activity.

Kritikan senada muncul dari pakar-pakar (hukum) lingkungan yang menyatakan bahwa seharusnya pengertian pembangunan berkelanjutan tidak lagi berangkat dari anthropocentrism yang menyatakan bahwa perlindungan dan pelestarian lingkungan dilakukan sepenuhnya untuk memenuhi kebutuhan manusia. $^{22}$

Development of the No-Harm Rule (August 25, 2014). PluriCourts Research Paper No. 14-17. Available at SSRN: https://ssrn.com/abstract=2486421.

21 Id. pp 3-4.

${ }^{22}$ Lihat Bryan Norton, "Environmental Ethics and Weak Anthropocentrism”, Journal Environmental Ethics, Vol. 6: 2: 326-338. Bdgkan: Katie McShane, "Anthropocentrism vs Nonanthropocentrism: Why should we care?" Environmental Values, 16 (2017) [169-185] \& Ronald E. Purser, Changkil Park \& Alfonso Montuori, "Anthropocentrism: Toward an Ecocentric Organization Paradigm?" The Academy of Management Review, Oct. 1995, Vol 20: 4: 1053-1089. Mereka menyatakan bahwa 'antrophocentrism is the belief that there is a clear and morally dividing line between humankind and the rest of nature, that humankind is the only principal source of value meaning in the world (p. 1054). 
Di samping itu, pemahaman sustainable development tetap harus kita kaitkan dengan differensiasi antara kebutuhan dan kepentingan Negara berkembang versus Negara maju. Ketidakadilan pemanfaatan sumber daya alam (lingkungan termasuk hutan) dipandang merupakan bagian dari struktur dan tatanan ekonomi dunia di masa lampau (sejarah imperialisme-kolonialisme) dan harus dikoreksi dengan: 1. pengakuan kedaulatan (sovereignty) termasuk hak berdaulat (sovereign right) dan hak yang tidak boleh diasingkan (inalienable right) dari Negara-negara berkembang untuk mengekploitasi lingkungan, sumber daya alam termasuk hutan untuk kepentingan pembangunan (yang juga terkait berkelindan dengan the right to development) dan: 2. Beban tanggung jawab pada Negara maju (termasuk bantuan pembiayaan) untuk mendukung kegiatan pelestarian-perlindungan lingkungan di Negara-negara berkembang.

\section{Common but Differentiated Responsibilities dalam Pengelolaan Lingkungan Hidup dan Hutan}

Sebagaimana diindikasikan di atas kiranya sudah jelas bahwa setiap negara diwajibkan (dalam hukum lingkungan internasional, sekalipun kadang lebih sebagai anjuran etikal) untuk peduli pada kelestarian lingkungan termasuk ke dalamnya perlindungan dan penjagaan kuantitas dan kualitas kawasan hutan. Kepedulian ini haruslah dikonkritkan ke dalam peraturan perundang-undangan, implementasi serta penegakannya. Namun dalam hukum lingkungan internasional (pengelolaan lingkungan hidup, termasuk ke dalamnya kawasan hutan), tanggungjawab ini dibedakan antara Negara berkembang (yang dianggap masih berkewajiban dan perlu mengeksploitasi sumber daya alam, lingkungan dan hutan demi pembangunan) dengan Negara maju (yang sudah terlebih dahulu mengeksploitasi sumber daya alam dan sekarang ini "wajib” membantu Negara berkembang untuk mengelola dengan baik sumber daya alam, lingkungan atau hutan yang tersisa. 
Indikasi dari perbedaan sudut pandang dan kepentingan ini muncul dalam penegasan adanya tanggung jawab sama namun dengan beban berbeda-beda (common but differentiated responsibilities). Ditegaskan oleh Deklarasi Rio 1992 (Principle 7):

States shall cooperate in a spirit of global partnership to conserve, protect and restore the health and integrity of the Earth's ecosystem. In view of the different contributions to global environmental degradation, States have common but differentiated responsibilities. The developed countries acknowledge the responsibility that they bear in the international pursuit of sustainable development in view of the pressures their societies place on the global environment and of the technologies and financial resources they command;

Selain itu apa yang dapat dicatat dari prinsip yang termuat dalam Rio Declaration 1992 di atas adalah pengakuan dan penegasan adanya kontribusi Negara maju (developed states) terhadap perusakan lingkungan selama sekian dekade dan sebab itu adanya tanggungjawab yang sama sekalipun berbeda dengan Negara berkembang (developing states). Artinya urusan penetapan dan perincian kewajiban melindungi dan melestarikan lingkungan hidup (dan sumber daya alam) di tataran (hukum) internasional harus beranjak dari pembedaan kategori Negara maju dan Negara berkembang dan sumbangan kedua kategori Negara pada perusakan dan degradasi lingkungan secara umum. Pengandaiannya adalah Negara maju bisa semaju sekarang (dan meninggalkan Negara-negara berkembang) karena sudah terlebih dahulu berkesempatan untuk jangka waktu cukup lama mengeksploitasi sumber daya alamnya, termasuk yang dahulu berada di Negara-negara jajahan. Kesempatan serupa harus diberikan dan dinikmati Negara berkembang, khususnya untuk mengejar ketertinggalan dari Negara maju.

Tersembunyi di dalam pengandaian di atas adalah persoalan bagaimana memaknai keadilan lingkungan (environmental atau ecological justice) atau intragenerational equity (di Negara berkembang dan Negara maju) yang dikaitkan 
dengan kemajuan atau pertumbuhan ekonomi yang sudah lebih dahulu dinikmati dan dicapai Negara-negara maju. Karena apa yang Negara berkembang tuntut atas nama keadilan ini adalah pengakuan dan penghormatan Negara-negara maju atas hak penuh (sovereign right) dan tidak boleh diasingkan (inalinenable) dari Negara berkembang untuk mengeksploitasi lingkungan (sumberdaya alam, termasuk hutan) yang berada di bawah yurisdiksi teritorialnya untuk pembangunan negara-bangsa-nya sendiri.

Tuntutan seperti di atas sekaligus dapat kita telusuri muncul dan terkait berkelindan dengan the New Economic World Order (1974). ${ }^{23}$ Dokumen ini pada prinsipnya menyatakan adanya ketidakadilan struktural antara Negara maju dengan Negara-negara baru merdeka (berkembang) dan harus dihormatinya hak (bahkan) kewajiban Negara berkembang untuk mengejar ketertinggalan (ekonomi) dengan bantuan penuh dari Negara-negara maju. Hal ini tegas dinyatakan di dalam konsiderans the New World Economic Order sebagai berikut:

The developing countries, which constitute 70 per cent of the world's population, account for only 30 per cent of the world's income. It has proved impossible to achieve an even and balanced development of the international community under the existing international economic order. The gap between the developed and the developing countries continues to widen in a system which was established at a time when most of the developing countries did not even exist as independent States and which perpetuates inequality

Deklarasi di atas pada gilirannya menegaskan hak dan kewajiban Negara (berkembang) untuk mengeksploitasi sumber daya untuk kepentingan pembangunan rakyat dan bangsanya. The Charter of Economic Rights and Duties of States (1974) ${ }^{24}$ yang juga dirujuk dokumen di atas menegaskan (Article 2(1)):

${ }^{23}$ A/RES/S-6/3201, 1 May 1974, Sixth Special session Agenda item 7, Resolution adopted by the General Assembly 3201 (S-VI). Declaration on the Establishment of a New International Economic Order.

${ }^{24}$ A/RES/29/3281;12 December 1974; Twenty-ninth session Agenda item 48;Resolution adopted by the General Assembly 3281 (XXIX). Charter of Economic Rights and Duties of States. 
Every State has and shall freely exercise full permanent sovereignty, including possession, use and disposal, over all its wealth, natural resources and economic activities.

Namun kebebasan tersebut tidak boleh dimaknai secara absolut, karena khususnya berkaitan dengan pemanfaatan dan pengelolaan lingkungan dan sumber daya secara umum (common but differentiated responsibilities), Principle 11 Rio Declaration menegaskan:

States shall enact effective environmental legislation. Environmental standards, management objectives and priorities should reflect the environmental and development context to which they apply. Standards applied by some countries may be inappropriate and of unwarranted economic and social cost to other countries, in particular developing countries.

Dari kutipan di atas selanjutnya dapat dicermati bahwa differensiasi (pembedaan tanggung jawab) menyangkut kewajiban sekaligus kewenangan negara-negara untuk menetapkan standar (perlindungan, pelestarian, pemanfaatan) lingkungan, sasaran pengelolaan serta prioritas secara berbedabeda. Hal itu tidak dapat dan boleh dipukul rata untuk Negara maju dan Negaranegara berkembang. Standar perlindungan dan pelestarian lingkungan harus disesuaikan dengan kebutuhan Negara (berkembang) untuk membangun secara berkelanjutan (sustainable development) yang niscaya harus dikaitkan dengan kebutuhan generasi sekarang yang ada di Negara-negara tersebut (maju dan berkembang). Tidak ada penjelasan, namun demikian, apakah standar perlindungan harus dikaitkan pada tingkat kerentanan dan kegawatan kondisi lingkungan hidup.

Apa yang disebut di atas, namun demikian, sekaligus membuka peluang bagi Negara-negara (terutama berkembang) untuk menerapkan standar lingkungan, tujuan atau sasaran pengelolaan dan prioritas yang lebih condong pada eksploitasi daripada konservasi. Prinsip di atas yang terkait dengan prinsip integritas (ikhtiar menyeimbangkan kebijakan eksploitasi dengan kebutuhan 
konservasi) dapat terus digunakan Negara berkembang untuk membenarkan kebijakan pengelolaan dan pemanfaatan yang de facto justru tidak berkelanjutan. Prinsip pembedaan tanggung jawab Negara juga menjadi titik tolak prinsipprinsip yang termuat dalam forest principles yang disebut di atas. Prinsip atau elemen pertama menyebutkan:

1. (a) States have, in accordance with the Charter of the United Nations and the principles of international law, the sovereign right to exploit their own resources pursuant to their own environmental policies and have the responsibility to ensure that activities within their jurisdiction or control do not cause damage to the environment of other States or of areas beyond the limits of national jurisdiction.

(b) The agreed full incremental cost of achieving benefits associated with forest conservation and sustainable development requires increased international cooperation and should be equitably shared by the international community.

Sedangkan Prinsip kedua menegaskan kewenangan Negara yang bersumber dari kedaulatan Negara untuk mengelola sumber daya hutan. Prinsip kedua menyatakan:

2. (a) States have the sovereign and inalienable right to utilize, manage and develop their forests in accordance with their development needs and level of socio-economic development and on the basis of national policies consistent with sustainable development and legislation, including the conversion of such areas for other uses within the overall socio-economic development plan and based on rational land-use policies.

Untuk mencegah Negara berkembang berdasarkan prinsip kedua di atas justru mengembangkan kebijakan yang tidak pro lingkungan atau hutan, maka Prinsip 7 menyatakan:

a) Efforts should be made to promote a supportive international economic climate conducive to sustained and environmentally sound development of forests in all countries, which include, inter alia, the promotion of sustainable patterns of production and consumption, the eradication of poverty and the promotion of food security. 
(b) Specific financial resources should be provided to developing countries with significant forest areas which establish programmes for the conservation of forests including protected natural forest areas. These resources should be directed notably to economic sectors which would stimulate economic and social substitution activities.

Pembacaan positif atas prinsip-prinsip di atas diberikan, misalnya oleh Lavanya Rasjamani ${ }^{25}$. Prinsip CBDR (dalam hukum lingkungan internasional) dengan konkrit mengidentifikasi perbedaan pada Negara-negara, yaitu kontribusi pada kerusakan lingkungan hidup dan kemampuan Negara-negara melakukan tindakan untuk mengatasi masalah lingkungan hidup. Dapat diduga bahwa pemahaman differensiasi tanggungjawab ini dilandasi pada semangat keadilan lintas waktu dan lintas generasi. ${ }^{26}$ Tafsiran sedikit berbeda, sekalipun tetap positif, diberikan oleh David Hunter et.al. :27

CBDR provides a conceptual framework for compromises and cooperation in meeting future environmental challenges. Because it allows countries that have different positions with respect to specific environmental issue to be treated differently.

Pembedaan tanggung jawab (different responsibilities), dengan demikian, secara tegas mengacu pada perbedaan kemajuan dan/atau pertumbuhan ekonomi (Negara maju dan Negara berkembang). Hal ini konkrit muncul dalam tuntutan yang lebih rendah pada Negara berkembang dalam pengembangan standar

${ }^{25}$ Lavanya Rasjamani, (2006), Differential Treatment in International Environmental Law, Oxford University Press, hlm. 130,

${ }^{26}$ Alexander Kiss et all menyatakan prinsip CBDR: could encompass and in some formulation the notion of historic responsibility of the industrialized North for most environmental degradation used to achieve its wealth. (dan sebab itu adalah juga) legal concept involving redistribution of wealth based on notions of restitution or unjust enrichment. Alexander Kiss \& Dinah Sheldon, (2007), A Guide to International Environmental Law, Leiden: Martinus Nijhoff Publishers, p. 107. Senada dengan itu adalah Matsui Yoshiro, "The Principle of Common but Differentiated Responsibilities" in Schrijver, Nico, Weiss and Friedl (eds.), (2004) International Law and Sustainable Development: Principles and Practices, Leiden: Martinus Nijhoff Publishers, pp. 73 74. Cf. O'Connel, Andrew J., "Tragedy of the Common but Differentiated Responsibilities: A Critique", CEPMLP Annual Review - CAR Vol. 16 (2013):

27 David Hunter, James Salzman, Durwood Zaelke, (1998), International Environmental Law and Policy, Foundation Press, New York, hlm. 358. 
lingkungan hidup dan peluang untuk justru mengenyampingkan semua standar lingkungan untuk kepentingan mengejar ketertinggalan (dan/atau pembangunan ekonomi).

Dengan kata lain, kepentingan pembangunan akan selalu didahulukan daripada usaha melestarikan dan mempertahankan kawasan atau tutupan hutan. Selain itu, beban biaya untuk mengelola atau justru tidak memanfaatkan sumberdaya yang ada (hutan) untuk kepentingan konservasi (atau penjagaan keanekaragaman hayati), beban lebih banyak ditimpakan pada Negara maju. Munculnya anggapan bahwa hanya Negara kaya yang mampu peduli lingkungan dan menanggung biaya yang diperlukan untuk itu kiranya berkaitan dengan pemahaman keliru prinsip di atas.

Sekalipun begitu CBDR jelas membenarkan pembebanan tanggung jawab yang tidak sama antara Negara maju dengan Negara berkembang, khususnya berkaitan dengan pengelolaan lingkungan hidup. Dengan kata lain: ${ }^{28}$

The principle therefore provides for asymmetrical rights and obligations regarding environmental standards, and aims to induce broad State acceptance of treaty obligations, while avoiding the type of problems typically associated with a lowest common denominator approach. The principle also reflects the core elements of equity, placing more responsibility on wealthier countries and those more responsible for causing specific global problems. Perhaps more importantly, the principle also presents a conceptual framework for compromise and co-operation in effectively meeting environmental challenges.

Membaca kutipan di atas muncul kesan kuat bahwa prinsip CBDR kuat didominasi kehendak dan semangat untuk mendekonstruksi sistem dan struktur ekonomi yang dianggap lebih menguntungkan Negara-negara maju (Utara). Pada gilirannya hal itu membuka peluang bagi Negara berkembang untuk menyandera Negara maju, yaitu untuk memberikan sumbangan (bantuan dan dukungan

28 The Principle of Common But Differentiated Responsibilities: Origins and Scope For the World Summit on Sustainable Development 2002, Johannesburg, 26 August. http://cisdl.org/public/docs/news/brief_common.pdf. 
finansial, termasuk teknologi) demi pengelolaan baik sumber daya alam (hutan) Negara berkembang.

Itu pula sebabnya princip CBDR dengan penekanan pada pembedaan tanggung jawab Negara berkembang yang berbeda (lebih ringan) daripada negara maju dikritik terutama oleh Negara-negara maju. Disebutkan bahwa prinsip CBDR dibangun atas dasar 6 mitos, yaitu: 29

1) CBDR opposes the principle of universality; 2) it is an historic 'relic' and no longer relevant; 3) it is only applicable to the environmental dimension; 4) it is only a political principle, with no technical relevance; 5) the North-South divide has vanished; and 6) it implies inaction by some countries.

Penyebutan prinsip CBDR sebagai mitos secara langsung menyerang keabsahan dan kekuatan mengikat dari prinsip ini di tataran hukum (lingkungan) internasional. Terhadapnya dapat diberikan catatan sebagai berikut, prinsip CBDR terdata muncul dalam sejumlah besar perjanjian internasional ${ }^{30}$ : The 1972 London Convention menyebutkan kewajiban Negara pihak untuk mengadopsi measures "according to their scientific, technical and economic capabilities." Kebutuhan khusus Negara berkembang juga diakui dalam Pasal 11(3) the 1976 Barcelona Convention dan dalam preamble to the UN Convention on the Law of the Sea, yang menyebutkan perlunya diperhatikan: "circumstances and particular requirements," of their "specific needs and special circumstances," or of their "special conditions" and "the fact that economic and social development and eradication of poverty are the first and overriding priorities of the developing country parties." Diferensiasi tanggun jawab juga disebut dalam the Climate Change Convention yang mengakui "special needs and special circumstances of

${ }^{29}$ Meine van Noordwijk, CAPRi Blog: Tragedy of the "Common But Differentiated Responsibilities" Resolved, But Is the Principle Applied Consistently? (January 4, 2016). Available at: http://capri.cgiar.org/2016/01/04/

30 The Principle of Common But Differentiated Responsibilities: Origins and Scope For the World Summit on Sustainable Development 2002, Johannesburg, 26 August. 
developing country parties, especially those that are particularly vulnerable to the adverse effects of climate change". Dengan cara serupa 1987 Montreal Protocol menyebutkan bahwa: the special situation of developing countries entitles them, provided they provided they meet certain conditions, to delay their compliance with control measures. Perjanjian-perjanjian menegaskan keberlakuan prinsip CBDR sebagai prinsip hukum yang tidak boleh dikesampingkan begitu saja.

Namun satu hal yang perlu diperhatikan ialah bahwa perjanjian-perjanjian di atas berbeda dari Rio Declaration dan Forest Principles, tidak lagi beranjak dari sejarah masa lalu dan ketidakadilan strutural ekonomi Utara-Selatan yang mungkin masih relevan pada era 1950-1970. Titik tolaknya adalah perbedaan situasi-kondisi yang memang layak diperhitungkan dan bila diabaikan justru mengakibatkan ketidakadilan dalam pembebanan tanggung jawab.

Pada lain pihak, lagi pula banyak dari Negara-negara di Selatan (berkembang) tidak lagi dapat dan layak digolongkan sebagai Negara berkembang, misalnya Singapura, Korea Selatan dan mungkin juga Malaysia. Bagaimana pula kita menggolongkan Brunei Darussalam, misalnya, Negara kaya minyak yang mungkin dari segi kemampuan teknologi jauh di bawah Negaranegara maju Utara, tidak dapat digolongkan Negara yang mengalami kesulitan dalam membiayai pembangunan termasuk kegiatan pelestarian lingkungan.

Kata kunci lainnya adalah bahwa pembedaan tanggung jawab di dalam perjanjian-perjanjian di atas tidak bersifat permanen. Sebagaimana disebut dengan tegas dalam Montreal Protocol 1987 di atas, pembedaan itu sekadar berurusan dengan menunda untuk sementara waktu pemenuhan sejumlah kewajiban. Ini kiranya juga muncul dalam pemberlakuan WTO dan instrument- 
instrumen terkait dengannya (GATT, GATS, TRIMs, TRIPs) ${ }^{31}$ dan pembentukan schedule of commitments.

Tentu pemahaman di atas belum tentu yang paling benar dan dalam kenyataan menjadi rujukan di tataran hukum lingkungan internasional. Namun dari uraian di atas setidaknya dapat ditelusuri kapan dan di mana salah kaprah tentang prinsip common but differentiated responsility bisa muncul dan memberikan alasan bagi Negara berkembang (termasuk Indonesia) untuk sekalipun atau justru karena menerima penyebutan hutan hujan tropika sebagai common heritage of mankind yang menjadi common concern dari masyarakat internasional untuk mengabaikan total kewajiban (responsibilities) di bawah hukum internasional untuk menjaga dan tidak menyalahgunakan sumber daya alam (hutan) sehingga menimbulkan kerugian bagi masyarakat internasional ataupun negara tetangga.

\section{Penutup}

Sebagai suatu konsep atau gagasan dalam hukum lingkungan internasional, common but differentiated responsibilities, menekankan pentingnya equitable share

31 Vice Yu, Special and Differential Treatment (SDT) and Common but Differentiated Responsibility (CDR): Principles in Favor of Developing and LDC Countries in the Trade and Environment Negotiations. Available at http://www.iatp.org/files/Special_and_Differential_Treatment_SDT_ and_Com.htm./ Disebutkan di dalamnya bahwa: "Paragraph 2 of the Doha Ministerial Declaration states that the needs and interests of developing and LDC countries must be placed at the heart of the Doha Work Program. In the same vein, the trade and environment negotiations mandated in Paragraphs 31(i) and (iii) of the Doha Ministerial Declaration must take account of the needs and interests of developing and LDC countries. (...)As complementary principles in different areas of international law such as international trade law and international environmental law, both the principle of SDT and the principle of CDR must be taken into account in instances in which these two fields of international law meet and interact. One such instance of legal interaction is the mandated Paragraph 31(i) negotiations on the "relationship between existing WTO rules and specific trade obligations set out in multilateral environmental agreements (MEAs)" as well as the Paragraph 31(iii) negotiations on tariff liberalization in environmental goods and services. In both of these sets of negotiations, both SDT and CDR principles are applicable and must be operationalized. This will ensure that the outcomes of these negotiations take into account the needs and interests of developing and LDC countries". (...) GATT 1994 Articles XVIII, XXXVI through XXXVIII. WTO juga membuka peluang bagi developing countries untuk menikmati secara umum lower levels of bound commitments in the GATT as well as in the GATS. 
of responsibilities antara Negara-negara maju dengan Negara berkembang. Kiranya tidak ada yang salah dengan ini, sepanjang parameternya tidak sekadar pembedaan antara negara maju dan berkembang dan sisa-sisa kemarahan akibat masa lalu kolonialisme-imperialisme. Instrumen atau dokumen hukum internasional lain justru mengaitkannya dengan kondisi sosial-ekonomi atau lingkungan yang nyata berbeda, bukan sekadar pemisahan maju (Barat atau Utara) dengan berkembang (Timur atau Selatan).

Persoalan lain adalah adanya penegasan berulang kali di dalam Rio Declaration dan Forest Principles akan sovereign and inalienable right dari Negaranegara (berkembang) untuk mengeksploitasi lingkungan (termasuk sumberdaya alam dan hutan) demi pembangunan. Pesan yang ditangkap Negara berkembang alih-alih kewajiban untuk menyelenggarakan pembangunan secara berkelanjutan (itupun dimaknai sebagai kewajiban etikal ketimbang hukum) adalah adanya jaminan kebebasan seluas-luasnya untuk mengeksploitasi lingkungan. Pemaknaan konsep sustainable development yang masih anthropocentric dan pengaruhnya pada bagaimana konsep atau prinsip turunan dikembangkan mengakibatkan Negara berkembang, termasuk Indonesia, lebih peduli pada hak yang tidak boleh diganggu gugat ketimbang perhatian pada kewajiban memelihara dan menjaga yang diimplikasikan penyebutan hutan hujan tropika sebagai common heritage.

\section{Daftar Pustaka}

\section{Buku}

Have. Henk ten (2016), Global Bioethics: An Introduction, New York. Routledge.

Hunter. David. James Salzman, Durwood Zaelke, (1998), International Environmental Law and Policy, Foundation Press, New York. IUCN/UNEP/WWF. (1991), Caring for the Earth: A Strategy for Sustainable Living, Gland, Switzerland.

Kiss. Alexander \& Dinah Sheldon, (2007), A Guide to International Environmental Law, Leiden: Martinus Nijhoff Publishers. 
Secretariat of the Convention on Biological Diversity (2000), Sustaining life on Earth: How the Convention on Biological Diversity promotes nature and human well-being, the United Nations Environment Programme (UNEP).

Sands. Phillippe. et al. (eds), (2012), Principles of International Environmental Law, 3rd ed. Cambridge University Press. P. 207.

Rasjamani. Lavanya, (2006), Differential Treatment in International Environmental Law, Oxford University Press.

The World Commission on Environment and Development's (the Brundtland Commission), Report (1987): Our Common Future, Oxford: Oxford University Press.

Yoshiro. Matsui. "The Principle of Common but Differentiated Responsibilities" in Schrijver, Nico, Weiss and Friedl (eds.), (2004) International Law and Sustainable Development: Principles and Practices, Leiden: Martinus Nijhoff Publishers.

Artikel

Adams. W.M., The Future of Sustainability: Re-thinking Environment and Development in the Twenty-first Century; Report of the IUCN Renowned Thinkers Meeting, 29-31 January 2006; www.iucn.org.

Emas. Rachel. Brief for GSDR 2015, "The Concept of Sustainable Development: Definition and Defining Principles" https://sustainabledevelopment. un.org/content/documents/5839GSDR\%202015 SD concept definiton re v.pdf.

FA0, "World Deforestation Decrease, but Remains Alarming in Many Countries." http://www.fao.org/news/story/en/item/40893/icode/

Fitzmaurice, Malgosia, History of Article 38 of the Statute of the International Court of Justice (May 3, 2016). Queen Mary School of Law Legal Studies Research Paper No. 232/2016. Available at https://ssrn.com/sol3/astract=2774354.

Indonesia's forest fires: everything you need to know: The fires devastating Indonesia have been called a 'crime against humanity'. How did they start, what damage are they causing and who's to blame? https://www.theguardian.com/sustainablebusiness/2015/nov/11/indonesia-forest-fires-explained-haze-palm-oiltimber-burning.

Jervan, Marte., The Prohibition of Transboundary Environmental Harm. An Analysis of the Contribution of the International Court of Justice to the Development of the No-Harm Rule (August 25, 2014). PluriCourts Research Paper No. 1417. Available at SSRN: https://ssrn.com/abstract=2486421 .

Lang. Winfried, UN-Principles and International Environmental Law, Max Planck UNYB 3 (1999):157-172. 
McShane. Katie, "Anthropocentrism vs.Nonanthropocentrism: Why should we care?" Environmental Values, 16 (2017) [169-185]

Noordwijk. Meine van, CAPRi Blog: Tragedy of the "Common But Differentiated Responsibilities" Resolved, But Is the Principle Applied Consistently? (January 4, 2016). Available at: http://capri.cgiar.org/2016/01/04/

Norton. Bryan, "Environmental Ethics and Weak Anthropocentrism", Journal Environmental Ethics, Vol. 6: 2: 326-338.

O'Connel, Andrew J., "Tragedy of the Common but Differentiated Responsibilities: A Critique", CEPMLP Annual Review - CAR Vol. 16 (2013).

Porte. Sarah. "Can Indonesia's forest fires be put out for good?" http://www.bbc.com/news/business-35770490

Purser. Ronald E., Changkil Park \& Alfonso Montuori, "Anthropocentrism: Toward an Ecocentric Organization Paradigm?" The Academy of Management Review, Oct. 1995, Vol 20: 4: 1053-1089.).

The Principle of Common But Differentiated Responsibilities: Origins and Scope For the World Summit on Sustainable Development 2002, Johannesburg, 26 August. http://cisdl.org/public/docs/news/brief_common.pdf.

Vidal. John. "Rate of deforestation in Indonesia overtakes Brazil, says study", https://www.theguardian.com/environment/2014/jun/29/.

Yu. Vice, Special and Differential Treatment (SDT) and Common but Differentiated Responsibility (CDR): Principles in Favor of Developing and LDC Countries in the Trade and Environment Negotiations. Available at http://www.iatp.org/files/Special_and_Differential_Treatment_SDT_and_C om.htm./

\section{Situs (websites)}

https://www.cbd.int/

http://www.un.org/en/events/righttodevelopment/pdf/rtd_at_a_glance.pdf

http://www.worldbank.org/depweb/english/sd.html.

\section{Instrumen Hukum (Internasional)}

UN Charter (1948).

A/RES/S-6/3201, 1 May 1974, Sixth Special session Agenda item 7, Resolution adopted by the General Assembly 3201 (S-VI). Declaration on the Establishment of a New International Economic Order.

A/RES/29/3281;12 December 1974;Twenty-ninth session Agenda item 48; Resolution adopted by the General Assembly 3281 (XXIX). Charter of Economic Rights and Duties of States.

Declaration of the United Nations Conference on the Human Environment. http://www.unep.org/documents.multilingual/default.asp?documentid=9 $7 \&$ articleid $=1503$. 
The Declaration on the Right to Development, adopted in 1986 by the United Nations General Assembly (GA) in its resolution 41/128.

A/CONF.151/26 (Vol. III); General Assembly Distr. GENERAL 14 August 1992. REPORT OF THE UNITED NATIONS CONFERENCE ON ENVIRONMENT AND DEVELOPMENT(Rio de Janeiro, 3-14 June 1992) Annex III:NON-LEGALLY BINDING AUTHORITATIVE STATEMENT OF PRINCIPLESFOR A GLOBAL CONSENSUS ON THE MANAGEMENT, CONSERVATION AND SUSTAINABLE DEVELOPMENT OF ALL TYPES OF FORESTS

The 1992 Rio Declaration on Environment and Development.

The 1993 Vienna Declaration and Programme of Action.

The Millennium Declaration. United Nations A/RES/55/2. General Assembly Res.. 18 September 2000, Fifty-fifth session. Agenda item 60 (b)00 55951.

The 2002 Monterrey Consensus.

The Principle of Common But Differentiated Responsibilities: Origins and Scope For the World Summit on Sustainable Development 2002, Johannesburg, 26 August.

The 2005 World Summit Outcome Document.

The 2007 Declaration on the Rights of Indigenous Peoples 